\title{
PENGUKURAN TINGKAT KEMATANGAN SIMASTER MENGGUNAKAN COBIT 4.1 DI SMA PLUS BBS BOGOR
}

\author{
Irmayansyah, Agustina Rahayu Putri \\ Program Studi Sistem Informasi \\ STIKOM BINANIAGA.
}

\begin{abstract}
SMA Plus BBS has Academic Information System that manage all academic activities that is Integrated School Management Information System (SIMASTER). SIMASTER is a Web-based Academic Information System, SIMASTER provides easy management of school management. At this time, SIMASTER is applied well, all academic activities have been assisted by SIMASTER. Monitoring process has been done by the manager SIMASTER. This needs to be proven through the IT monitoring and oversight assessment process. The purpose of this study is to determine the level of maturity monitoring and evaluation process SIMASTER SMA Plus BBS. Research method used in this research is survey method that is by taking or collecting data through questioner. The results of calculations from all sub domains Monitor and Evaluate IT Performance can be seen that the maturity level of the SIMASTER information system is at the level of 1.34 (one point thirty four) or at level 1 (Initial / Ad Hoc), meaning management recognizes the need to collect and assess information about the monitoring process. Process collection and assessment standards have not been identified. Monitoring is implemented and the metrics are selected on a case-by-case basis, according to the specific IT project requirements.
\end{abstract}

Keywords: Cobit, Maturity Level, Governance, Monitor and Evaluate, SIMASTER.

\begin{abstract}
ABSTRAK
SMA Plus BBS mempunyai Sistem Informasi Akademik yang mengatur seluruh kegiatan akademik yaitu Sistem Informasi Manajemen Sekolah Terpadu (SIMASTER). SIMASTER adalah Sistem Informasi Akademik berbasis web, SIMASTER memberikan kemudahan dalam pengelolaan manajemen sekolah. Pada saat ini, SIMASTER diterapkan secara baik, seluruh kegiatan akademik telah dibantu dengan adanya SIMASTER. Proses pengawasan telah dilakukan oleh pengelola SIMASTER. Hal ini perlu dibuktikan melalui proses penilaian pengawasan dan pengelolaan TI. Tujuan penelitian ini adalah untuk mengetahui tingkat kematangan proses pengawasan dan evaluasi SIMASTER SMA Plus BBS. Metode penelitian yang digunakan dalam penelitian ini adalah metode survey yaitu dengan mengambil atau mengumpulkan data melalui kuesioner. Hasil perhitungan dari seluruh sub domain Monitor and Evaluate IT Performance dapat diketahui bahwa tingkat kematangan (maturity level) pada sistem informasi SIMASTER berada pada tingkat 1,34 (satu koma tiga puluh empat) atau berada pada level 1 (Initial / Ad Hoc), artinya manajemen mengakui kebutuhan untuk mengumpulkan dan menilai informasi tentang proses pemantauan. Standar pengumpulan dan penilaian proses belum teridentifikasi. Pemantauan dilaksanakan dan metrik yang dipilih atas dasar kasus per kasus, sesuai dengan kebutuhan proyek IT yang spesifik.
\end{abstract}

Kata Kunci: Cobit, Maturity Level, Tata Kelola, Monitor and Evaluate, SIMASTER

\section{PENDAHULUAN}

\section{A. Latar Belakang}

Perkembangan Teknologi Informasi (TI) saat ini telah berkembang sedemikian cepatnya. Hal ini dirasakan dengan adanya penggunaan komputer yang telah banyak 
membantu kelancaran proses bisnis dalam dunia usaha. Seiring dengan perkembangan tersebut, persaingan dalam dunia bisnis menjadi semakin tinggi. Teknologi informasi telah terbukti memegang peranan penting dalam menciptakan value yang menjadi keunggulan bersaing bagi perusahaan. Penerapan informasi dalam dunia bisnis bukan saja menjadi pertimbangan penting, melainkan sangat strategis. Perusahaan-perusahaan modern yang menghadapi persaingan yang semakin ketat, terdorong untuk meningkatkan performansi, efisiensi, efektifitas serta daya saingnya dengan memanfaatkan sistem informasi (SI). (Anita Arifin, Budianto, Andreas Y, 2010).

Aktivitas utama dalam Instansi Pendidikan sesuai dengan fungsi utamanya yaitu sebagai penyelenggara pendidikan adalah layanan akademik. Dalam pelaksanaan layanan akademik ini perlu adanya penggunaan TI yang dapat mendukung kecepatan, kemudahan dan kenyamanan dalam layanan akademik, sehingga kualitas layanan akademik dapat diberikan kepada siswa.

Menurut Hardi Jamhur (2010:1) saat ini di banyak sekolah telah diperkenalkan teknologi informasi, mulai dari penggunaan keperluan penanganan administrasi sampai kepada kurikulum. Perkembangan ini adalah bentuk adaptasi sekolah terhadap pengembangan manajemen sekolah ke dalam pemanfaatan teknologi informasi tersebut. Salah satu indikasi sekolah yang dapat bersaing dan maju adalah sekolah yang benarbenar memanfaatkan sarana TI baik dalam proses belajar mengajar maupun administrasi.

Dalam proses akademik, SMA Plus BBS mempunyai Sistem Informasi Akademik yang mengatur seluruh kegiatan akademik yaitu Sistem Informasi Manajemen Sekolah Terpadu (SIMASTER). SIMASTER adalah Sistem Informasi Akademik berbasis web, SIMASTER memberikan kemudahan dalam pengelolaan manajemen sekolah. SIMASTER memberikan pelayanan akademik sekolah diantaranya :

1. Realtime Payment Report, merupakan laporan pembayaran baik SPP atau non SPP (fasilitas, DSP, dan lainnya) kepada orangtua siswa/wali seketika pada saat dibayarkan di Tata Usaha.

2. Realtime Presensi Report, merupakan laporan kehadiran siswa yang disampaikan kepada orangtua/wali seketika pada saat siswa masuk sekolah (terintegrasi dengan absensi sidik jari).

3. Realtime Reward and Punishment Report, laporan penghargaan atas prestasi atau pelanggaran siswa yang disampaikan kepada orangtua/wali saat siswa mendapatkan reward atau melakukan pelanggaran.

4. Auto Respon, untuk permintaan laporan pembayaran, nilai siswa dan lainnya. 
Pada saat ini SIMASTER sudah diterapkan, namun belum diterapkan dengan baik. Proses pengawasan telah dilakukan oleh pengelola SIMASTER. Dalam perjalanannya, SIMASTER mengalami pengembangan secara berkala, mulai dari Penerimaan Peserta Didik Baru (PPDB) secara online, CBT (Computer Based Test) aplikasi ujian online yang dilengkapi dengan bank soal yang dikategorikan berdasarkan kompetensi dasar setiap pelajaran. Hal ini membuktikan bahwa BBS Center SMA Plus BBS telah memanfaatkan sarana teknologi informasi. Namun, apakah proses pengawasan dan proses evaluasi TI yang dilakukan oleh BBS Center SMA Plus BBS sudah sesuai dengan standar tata kelola TI (IT Governance). Hal ini perlu dibuktikan melalui proses penilaian pengawasan dan evaluasi TI.

Proses pengawasan yang dilakukan oleh pengelola SIMASTER dilakukan setiap 1 (satu) kali dalam seminggu dan telah dilakukan, namun belum dilakukan dengan baik secara berkala. Proses pengawasan oleh Kepala IT BBS Center dilakukan setiap hari. Pengawasan tersebut diantaranya melakukan pengontrolan terhadap modul SIMASTER apakah telah digunakan sesuai dengan fungsinya atau tidak. Apabila modul belum digunakan maka pihak pengelola melaporkan kepada pihak sekolah untuk ditindak lanjuti kepada seluruh unit agar modul segera digunakan.

Proses evaluasi pada sistem informasi di SMA Plus BBS Bogor umumnya dilaksanakan secara reaktif, ini dilakukan apabila terjadi kesalahan atau insiden yang menyebabkan kerugian dan kehilangan. Pelaporan kinerja TI telah didokumentasikan, namun belum dilaporkan kepada pihak sekolah secara berkala.

COBIT 4.1 (Control Objective for Information and Related Technology) merupakan suatu framework yang terdiri dari domain dan proses yang digunakan untuk mengatur aktivitas dan logical structure. Metode COBIT dapat berguna untuk TI membuat hubungan kerja kebutuhan bisnis, organisasi teknologi informasi dapat membuat proses model, mengidektifikasi sumber daya teknologi informasi, dapat mengarahkan objektive kontrol manajemen. (Gandodiyoto, 2007, p:274).

Pada penelitian ini akan dilakukan penelitian pada suatu Institusi Pendidikan dengan menggunakan kerangka kerja yang sama yaitu COBIT. Penelitian ini akan menghitung tingkat kematangan proses pengawasan dan proses evaluasi Sistem Informasi Manajemen Sekolah Terpadu (SIMASTER) pada domain monitor and evaluate.

\section{B. Rumusan Masalah}

SMA Plus BBS Bogor mempunyai Sistem Informasi Akademik yang mengatur seluruh kegiatan akademik yaitu Sistem Informasi Manajemen Sekolah Terpadu 
(SIMASTER). SIMASTER adalah Sistem Informasi Akademik berbasis web, SIMASTER memberikan kemudahan dalam pengelolaan manajemen sekolah. Pada saat ini SIMASTER sudah diterapkan, namun belum diterapkan dengan baik. Proses pengawasan telah dilakukan oleh pengelola SIMASTER. Namun, apakah proses pengawasan dan pengelolaan TI yang dilakukan oleh BBS Center SMA Plus BBS sudah sesuai dengan standar tata kelola TI (IT Governance). Hal ini perlu dibuktikan melalui proses penilaian pengawasan dan pengelolaan TI.

\section{Tujuan Penelitian}

Adapun tujuan dari penelitian ini adalah :

1. Untuk mengetahui tingkat kematangan proses pengawasan SIMASTER SMA Plus BBS.

2. Untuk mengetahui tingkat kematangan proses evaluasi SIMASTER SMA Plus BBS.

\section{Ruang Lingkup dan Keterbatasan Penelitian}

Ruang lingkup dari penelitian ini adalah untuk mengetahui kematangan atau maturity level domain monitor and evaluate sub domain ME1 Monitor and Evaluate IT Performance pada SIMASTER yang digunakan oleh SMA Plus BBS Bogor. Adapun keterbatasan dari penelitian ini adalah sub domain yang digunakan terbatas pada sub domain ME 1. Monitor and Evaluate IT Performance dan sumber data diambil dari 9 (sembilan) orang responden yang mewakili tabel RACI Chart pada proses pengolahan data (IT Governance Institute, 2007).

\section{METODE}

Bentuk penelitian ini adalah bersifat analisis (non rekayasa) yaitu penelitian yang menitikberatkan pada aspek analisis. Pendekatan (approach) yang digunakan pada penelitian ini berorientasi pada aspek masalah yaitu untuk mengetahui seberapa tinggi tingkat kematangan tata kelola teknologi informasi. Sedangkan tujuan dasar dari penelitian ini adalah untuk mengetahui tingkat kematangan proses pengawasan dan proses evaluasi SIMASTER dengan menggunakan framework Cobit 4.1. Alur penelitian dapat dijelaskan sebagai berikut :

1. Penelitian dimulai dengan Identifikasi Masalah, pada tahap identifikasi dan perumusan masalah adalah melakukan identifikasi terhadap masalah yang ada untuk diangkat sebagai studi kasus dalam penelitian. Setelah didapatkan permasalahan dibuatkan rumusan masalah sebagai solusi untuk proses penyelesaian masalah. 
2. Pengumpulan data kuesioner. Pengumpulan data dilakukan dengan survei untuk mengumpulkan informasi-informasi yang menjadi sumber utama penelitian. Selain itu dengan menyebarkan kuesioner kepada responden untuk memperoleh informasi mengenai pernyataan-pernyataan yang diajukan pada penelitian ini.

3. Uji validitas dan reliabilitas kuesioner, hasil kuesioner yang telah dikumpulkan kemudian diteliti validitasnya dan diuji reliabilitasnya.

4. Pengolahan data, setelah diuji validitas dan reliabilitas data diolah menggunakan rumus indeks kematangan hingga didapatkan nilai maturity level.

5. Hasil, setelah data diolah akan menghasilkan tingkat kematangan maturity level domain monitor and evaluate sub domain ME1 Monitor and Evaluate IT Performance.

\section{A. Sumber Data dan Metode Pengumpulan Data}

Data yang digunakan dalam penelitian ini diperoleh dari hasil observasi langsung dan dengan menyebarkan kuesioner pada domain monitor and evaluate sub domain ME1 Monitor and Evaluate IT Performance kepada responden

\section{B. Instrumen Penelitian}

Dalam penelitian ini instrument yang digunakan menggunakan kuesioner yang disebar kepada responden dengan menggunakan pendekatan sebagai berikut :

1. Variabel Penelitian

Variabel yang digunakan pada penelitian ini adalah domain Monitor and Evaluate sub domain Monitor and Evaluate IT Performance yang terdapat dalam framework Cobit 4.1 yaitu :

a. ME1.1 Monitoring Approach

Membentuk kerangka pemantauan umum dan pendekatan untuk menentukan ruang lingkup, metodologi dan proses yang harus diikuti untuk mengukur solusi IT dan pelayanan, dan memantau kontribusi IT untuk bisnis. Mengintegrasikan kerangka kerja dengan perusahaan atau instansi.

b. ME1.2 Definition and Collection of Monitoring Data

Berfungsi untuk mendefinisikan suatu target kinerja dan minta mereka disetujui oleh instansi dan lainnya yang relevan stakeholder. Menentukan tolak ukur yang dapat digunakan untuk membandingkan sasaran, dan mengidentifikasi data yang tersedia yang dikumpulkan untuk mengukur target. Menetapkan proses untuk mengumpulkan data yang tepat waktu dan akurat untuk melaporkan kemajuan terhadap target.

c. ME1.3 Monitoring Method 
Menyebarkan metode pemantauan kinerja (misalnya, balanced scorecard) untuk menangkap nilai ukur yang menyediakan ringkasan kinerja IT, dan cocok dalam sistem pemantauan perusahaan.

d. ME1.4 Performance Assessment

Berfungsi untuk meninjau kinerja terhadap target, menganalisis penyebab dari setiap penyimpangan, dan memulai tindakan perbaikan untuk mengatasi penyebab permasalahan dengan waktu yang cepat dan tepat.

e. ME1.5 Board and Executive Reporting

Mengembangkan laporan manajemen senior pada kontribusi IT untuk bisnis, khususnya dalam hal kinerja perusahaan, IT-enabled, program investasi dan solusi, dan kinerja pelayanan penyampaian program individu. Termasuk dalam status melaporkan sejauh mana tujuan yang direncanakan telah dicapai.

f. ME1.6 Remedial Actions

Mengidentifikasi dan melakukan tindakan perbaikan berdasarkan kinerja, penilaian pemantauan dan pelaporan. Ini termasuk tindak lanjut dari semua pemantauan, pelaporan dan penilaian melalui :

1) Review, negosiasi dan pembentukan tanggapan manajemen,

2) Pengalihan tanggung jawab untuk perbaikan,

3) Pelacakan dari hasil tindakan yang dilakukan.

2. Penentuan Responden

Responden yang dipilih adalah responden yang mewakili tabel RACI (Responsibility, Accountability, Consulted, and Informed) pada proses pengolahan data (IT Governance Institute, 2007). Diagram RACI adalah bagian dari Responsibility Assignment Matrix (RAM), yaitu bentuk pemetaan antara sumberdaya dengan aktivitas dalam setiap prosedur.

Secara garis besar responden yang disertakan dapat dilihat pada Tabel 1 Responden Kuesioner.

Tabel 1. Responden Kuisioner

\begin{tabular}{|l|l|}
\hline \multicolumn{1}{|c|}{ RACI Respondent } & \multicolumn{1}{c|}{ Actual Respondent } \\
\hline Chief Information Officer $(R)$ & Kepala IT (1 orang) \\
\hline Chief Executive Officer $(A)$ & Kepala Sekolah (1 orang) \\
\hline Head Operation $(C)$ & $\begin{array}{l}\text { 1. Wakasek Bid. Akademik (1 orang) } \\
\text { 2. Wakasek Bid. Kesiswaan (1 orang) } \\
\text { 3. Kepala Tata Usaha (1 orang) }\end{array}$ \\
\hline Business Process Ownner $(I)$ & $\begin{array}{l}\text { 4. Staf Kurikulum (1 orang) } \\
\text { 5. Staf keuangan (1 orang) }\end{array}$ \\
\hline Head IT Administration $(I)$ & Staf IT (1 orang) \\
\hline Chief Architec $(I)$ & Pengelola IT (1 orang) \\
\hline
\end{tabular}


3. Skala Pengukuran Kuesioner

Skala yang digunakan dalam instrumen penelitian ini untuk mengukur kuesioner atau angket adalah skala likert. Menurut Sugiyono (2010:93) Skala likert digunakan untuk mengukur sikap, pendapat, dan persepsi seseorang atau sekelompok orang tentang fenomena sosial. Dengan menggunakan skala likert ketentuan skala sebagai berikut: Tidak setuju (bernilai 1), Kurang Setuju (bernilai 2), ,Setuju (bernilai 3), Sangat Setuju (bernilai 4)

4. Teknik analisis data

Pengolahan data ini bertujuan untuk menentukan maturity level berdasarkan Cobit yang telah dicapai oleh SMA Plus BBS Bogor pada saat ini. Dalam penelitian ini, untuk mengukur maturity level dilakukan dengan langkah-langkah sebagai berikut :

a. Konversi Nilai Kuesioner

Nilai skor 1 diberikan apabila responden menjawab pernyataan dengan TS (Tidak Setuju), nilai skor 2 diberikan apabila responden menjawab pernyataan dengan KS (Kurang Setuju), nilai skor 3 diberikan apabila responden menjawab pernyataan dengan $\mathrm{S}$ (Setuju), nilai skor 4 diberikan apabila responden menjawab pernyataan dengan SS (Sangat Setuju).

b. Rata-rata Konversi

Nilai yang telah dikonversi kemudian dibuatkan rata-rata nilai konversi dengan rumus :

$$
\text { Rata }- \text { rata konversi }=\frac{\text { Nilai Konversi }}{\sum \text { Pertanyaan Kuisioner }}
$$

c. Normalisasi

Nilai normalisasi didapat dari jumlah rata-rata konversi tiap level dibagi dengan jumlah level kemudian dikalikan dengan level.

$$
\text { Normalisasi }=\frac{\sum \text { rata }- \text { rata konversi per level }}{\sum \text { level }} \times \text { Level }
$$

d. Perhitungan Maturity Level

Indeks kematangan atribut diperoleh dari perhitungan total pilihan jawaban kuesioner dengan rumus dan pembobotan pilihan jawaban sebagai berikut :

$$
\text { Indeks kematangan }=\frac{\sum \text { Normalisasi }}{\sum \text { Responden }}
$$

e. Penilaian tingkat kematangan (maturity level) dilakukan dengan mempertimbangkan nilai indeks kematangan ( index maturity) pada 6 (enam) 
atribut kematangan. Rumus untuk menghitung indeks kematangan sebagai berikut :

$$
\text { Maturity Level }=\frac{\left.\sum \text { (Indeks kematangan atribut }\right)}{\sum \text { Sub Domain }}
$$

\section{HASIL DAN PEMBAHASAN}

\section{Hasil}

\section{A. Penyusunan Kuisioner}

Penyusunan kuesioner pada domain Monitor and Evaluate (ME) berdasarkan aktifitasaktifitas yang terdapat pada sub domain ME1. Pada setiap pernyataan dibagi menjadi 6 (enam) level pernyataan mulai dari level 0 non existence, level 1 initial ad/hoc, level 2 repeatable but institute, level 3 defined process, level 4 managed and measurable sampai dengan level 5 optimized.

1. Konversi Kuesioner

Pada tahap ini jawaban responden pada kuesioner dikonversikan sesuai dengan rentang jawaban kuesioner ke dalam 4 (empat) skala yaitu 1, 2, 3, dan 4 .

2. Uji Validitas dan uji Reliabilitas

Pengujian validitas kuesioner dilakukan dengan melakukan uji signifikansi. Untuk penentuan apakah suatu item layak digunakan atau tidak, yaitu dengan melakukan uji signifikansi koefisien korelasi pada taraf signifikansi 0,05 artinya suatu item dianggap valid jika berkorelasi signifikansi terhadap skor total item (Duwi Priyatno, SPSS Handbook, 2016:51). Dalam penelitian ini analisis korelasi product moment pearson digunakan untuk menguji validitas kuesioner. Uji reliabilitas dilakukan untuk mengetahui seberapa jauh hasil pengukuran tetap konsisten, apabila dilakukan pengukuran dua kali atau lebih terhadap gejala yang sama menggunakan alat pengukur yang sama. Konsistensi jawaban ditunjukkan oleh tingginya koefisien alpha (conbrach's alpha). Semakin mendekati 1 koefisien alpha dari variabel yang diuji semakin tinggi konsistensi jawaban skor butir-butir pernyataan. Dengan kata lain skor variabel tersebut makin dapat dipercaya hasil uji validitas kuesioner pada sub domain ME 1.6 dinyatakan valid, karena $r$ hitung bernilai lebih besar dari pada $\mathrm{r}$ tabel dengan tingkat signifikansi 5\% hasil uji reliabilitas pada kuesioner memiliki kriteria sangat tinggi. Konsistensi jawaban ditunjukkan oleh tingginya koefisien alpha. Semakin mendekati 1 (satu) koefisien alpha dari variabel yang diuji semakin tinggi konsistensi jawaban skor butir-butir pernyataan. Dengan kata lain skor variabel tersebut makin dapat dipercaya. 


\section{B. Pengolahan Data Kuisioner}

Pada tahapan ini berisikan hasil jawaban kuesioner dari responden kemudian diproses kedalam metode perhitungan skala likert dimana untuk jawaban Tidak Setuju bernilai 1, Kurang Setuju 2, Setuju 3, Sangat Setuju 4, kemudian dilanjutkan dengan perhitungan untuk menentukan nilai kematangan (maturity level) yang hasil perhitungannya adalah sebagai berikut:

1. Tahap menghitung rata-rata konversi yang didapat dari hasil perhitungan konversi dibagi jumlah pernyataan

2. Tahap menghitung normalisasi yang didapat dari hasil jumlah konversi dibagi jumlah pernyataan. Setelah itu hasil dari perhitungan normalisasi dikali dengan setiap level pernyataan

3. Perhitungan Maturity Level atau tingkat kematangan didapat dengan cara mencari nilai indeks kematangan atribut yang diperoleh dengan cara membangi jumlah nilai normalisasi dengan jumlah responden,

4. Perhitungan nilai maturity level atau tingkat kematangan yang dilakukan dengan cara membagi jumlah indeks kematangan atribut dengan jumlah subdomain. Hasil perhitungan maturity level dapat dilihat pada tabel 2

Tabel 2. Perhitungan Hasil Maturity Level Domain ME 1

\begin{tabular}{|c|c|c|c|}
\hline \multirow{2}{*}{ Domain } & $\begin{array}{c}\text { Monitor and } \\
\text { Evaluate IT } \\
\text { Performance }\end{array}$ & Indeks Kematangan & Maturity Level \\
\hline \multirow{4}{*}{$\begin{array}{c}\text { Monitor and } \\
\text { Evaluate }\end{array}$} & ME 1.1 & 1,29 & 1 \\
\cline { 2 - 4 } & ME 1.2 & 1,34 & 1 \\
\cline { 2 - 4 } & ME 1.3 & 1,27 & 1 \\
\cline { 2 - 4 } & ME 1.4 1,32 & 1 \\
\cline { 2 - 4 } & ME 1.5 & 1,25 & \\
\hline \multicolumn{2}{|c|}{ ME 1.6 } & $\mathbf{8 , 0 5}$ \\
\hline \multicolumn{2}{|c|}{} \\
\hline
\end{tabular}

\section{Pembahasan}

Berdasarkan tabel 2 dapat diketahui bahwa maturity level pada sub domain ME 1.1 Monitoring And Evaluate IT Performance sub domain ME 1.1 Monitoring Approach berada pada level 1 (Initial / Ad Hoc), artinya manajemen mengakui kebutuhan untuk melakukan proses pendekatan pengawasan tetapi belum dilakukan dengan baik. Pada sub domain ME 1.2 Definition and Collecting of Monitoring Data berada pada level 1 (Initial / Ad Hoc), artinya ketetapan untuk pengumpulan data pengawas sudah dilakukan dan manajemen mengakui kebutuhan tersebut namun belum dilakukan dengan baik.

Hasil pada sub domain ME 1.3 Monitoring Method berada pada level 1 (Initial / Ad $H o c)$, artinya standar pengawasan dan penilaian untuk mengawasi teknologi informasi tidak terstandarisasi. Sedangkan pada sub domain ME 1.4 Performance Assessment berada pada 
level 1 (Initial / Ad Hoc), ini artinya tidak ada metode analisa untuk mengatasi penyimpangan kinerja. Pemantauan terhadap pencapaian teknologi informasi belum diterapkan dengan baik.

Pada sub domain ME 1.5 Board and Executive Reporting berada pada level 1 (Initial / $A d \mathrm{Hoc}$ ), artinya ada pengawasan kinerja IT yang didokumentasikan dan dilaporkan kepada manajemen namun belum dilakukan dengan baik. Sedangkan pada sub domain ME 1.6 Remedial Actions berada pada level 2 (Repeatable but intuitive), artinya proses perbaikan terhadap tata kelola teknologi informasi pada SIMASTER belum dijalankan dengan sepenuhnya. Program yang telah dilaksanakan belum dilaporkan secara rinci, sehingga evaluasi belum berjalan dengan baik. Rekomendasi yang dapat diberikan untuk meningkatkan proses pengawasan dan evaluasi SIMASTER SMA Plus BBS adalah :

1. Perlu adanya prosedur yang baku tentang pengawasan SI/TI sehingga perlu menetapkan Standart Operational Procedure (SOP) untuk pelaksanaan proses pengawasan SI/TI. Panduan ini diharapkan dapat mengarahkan proses pengawasan SI/TI dan memastikan pencapaian kinerja sesuai dengan tujuan.

2. Perlu dipertimbangkan untuk melakukan pencatatan kinerja SI/TI secara tertulis, termasuk memberikan review dan melaporkan sejauh mana tujuan SI/TI telah dicapai.

3. Perlu dipertimbangkan untuk menerapkan metode pengawasan terhadap kinerja SI/TI (misalnya, balanced scorecard) untuk menjadi nilai ukur yang memperlihatkan ringkasan kinerja SI/TI.

\section{SIMPULAN DAN SARAN}

\section{Kesimpulan}

Berdasarkan hasil penelitian terhadap tata kelola teknologi informasi SMA Plus BBS Bogor domain Monitor and Evaluate pada sub domain Monitoring and Evaluate IT Performance dapat diketahui :

1. Tingkat kematangan per sub domain Monitoring and Evaluate It Performance diantaranya :

a. Tingkat kematangan sub domain ME 1.1 Monitoring Approach berada pada tingkat kematangan 1,29 atau level 1 (Initial / Ad Hoc).

b. Tingkat kematangan ME 1.2 Definition and Collecting of Monitoring Data berada pada tingkat kematangan 1,34 atau level 1 (Initial / Ad Hoc).

c. Tingkat kematangan ME 1.3 Monitoring Method berada pada tingkat kematangan 1,27 atau level 1 (Initial / Ad Hoc).

d. Tingkat kematangan ME 1.4 Performance Assessment berada pada tingkat kematangan 1,32 atau level 1 (Initial / Ad Hoc). 
e. Tingkat kematangan ME 1.5 Board and Executive Reporting berada pada tingkat kematangan 1,25 atau level 1 (Initial / Ad Hoc).

f. Tingkat kematangan ME 1.6 Remedial Actions Reporting berada pada tingkat kematangan 1,59 atau level 2 (Repeatable but intuitive).

2. Tingkat kematangan domain Monitoring and Evaluate sub domain Monitoring and Evaluate IT Performance berada pada tingkat kematangan level 1 yaitu 1,34. Artinya, manajemen mengakui kebutuhan untuk mengumpulkan dan menilai informasi tentang proses pengawasan, namun tidak ada proses pengawasan yang distandarisasi. Proses evaluasi terhadap pencapaian tata kelola SI/TI belum dilakukan dengan baik. Dokumentasi dan laporan data pengawas belum disampaikan dengan rinci kepada manajemen. Metode analisa untuk menilai pencapaian tata kelola SI/TI belum diterapkan sehingga proses evaluasi belum berjalan dengan baik

\section{Saran}

Saran yang dapat diberikan pada penelitian berikutnya yaitu :

1. Penelitian ini terbatas pada domain Monitoring and Evaluate (ME) sub domain Monitoring and Evaluate IT Performance saja. Pada penelitian selanjutnya dapat menggunakan seluruh domain Monitoring and Evaluate untuk mengetahui tingkat kematangan proses pengawasan dan proses evaluasi tata kelola SI/TI secara keseluruhan.

2. Evaluasi tata kelola SI/TI untuk selanjutnya dapat dilakukan pada semua proses yang ada pada domain dalam COBIT 4.1, yaitu Plan and Organise (PO), Acquire and Implement (AI) dan Deliver and Support (DS) untuk mendapatkan hasil evaluasi yang lebih lengkap.

3. Evaluasi tata kelola SI/TI selanjutkan mencari GAP (kesenjangan) antara kondisi tata kelola SI/TI saat ini dengan kondisi tata kelola SI/TI yang diharapkan.

\section{DAFTAR RUJUKAN}

Gondodiyoto, Sanyoto, 2007. Audit Sistem Informasi + Pendekatan Cobit, Penerbit Mitra Wacana Media, Jakarta.

Information Technology Governance Institute, 2007, COBIT 4.1: COBIT Framework, Control Objective, Executive Overview, Management Guidelines, Maturity Models, IT Governance Institute.

Jamhur, Hardi, (2010). Jurnal Ilmiah Teknologi Informasi dan Sains, STIKOM BINANIAGA, hal 1.

Obrien, James A, 2006. Pengantar Sistem Informasi Perspektif Bisnis dan Manajerial, Jakarta. 
Jurnal IImiah Teknologi - Informasi dan Sains (TeknoIS)

Volume 7 Nomor 1 Bulan M ei 2017

p-ISSN : 2087-3891 dan e-ISSN : 2597-8918

Sugiyono. (2010), Metode Penelitian Kuantitatif Kualitatif dan R\&D, Alfabeta, Bandung

Sutarman, 2009. Pengantar Teknologi Informasi, Penerbit Bumi Aksara, Jakarta.

Wahyudi, J.B,1992. Teknologi Informasi dan Produksi Citra Bergerak, Jakarta. 